\title{
A doubtful guest
}

\section{Impressions from a year at the Stout Centre}

\section{ELIZABETH KNOX}

I came to the Stout Research Centre well before my official term as PEN Fellow (February and March 1991). I inherited a room in the basement of 10 Wai-te-ata Road from Dorothea Turner, and moved into it in October 1990, with my notebooks, my postcards of Fra Angelico, Giovanni Bellini, Donatello; and with my rainbow-flasher fridge magnets. The japonica outside my window was still in bloom; waxeyes bumbled among its branches sucking nectar. Between the trees I had a view, a small serving of blue water. Everyday I walked from my flat on the Terrace, along Waite-ata Road, under - I fancied - a 'flowering Judas', a wattle, I believe. I wrote my essay 'Afraid', and a submission to the Indecent Publications Tribunal. People lost in the maze of paths through the university gardens tapped on my window to ask directions, one was Ken Douglas, cowled in a wet, grey nylon coat, caught in a downpour while looking for Policy Studies.

I kept to myself.

In December I moved into the Stout Centre proper, the PEN Fellow's second-floor room, a kind of incomplete pass of a gatehouse that pushes out towards the cement foundations of Jenness House. The room had windows on three walls and hours of afternoon sunlight. My rainbow-flashers drove me crazy, making multi-coloured flowers and doilies and shark's mouths on the pinkish walls.

Over Christmas and New Year I had the building to myself for three weeks. It was, I now know, a critical time for me. I had applied for the Stout Centre-PEN Fellowship with the declared intention of finishing my novel, Treasure. In those quiet weeks I sat down to write chapter three of part three, and surfaced twenty-one days later feeling childish and violent and sly. The zip was whistling, Valerie typing, everything was alive again. And me? I'd stopped breathing for a moment and was in heaven.

Right. Say I went out and had lunch with the other Stout Fellows. Pat Day had his radio on and was listening to some commentatortalkingabout the condition of the pitchat theBasin Reserve. He switched it off as people arrived and we all talked.

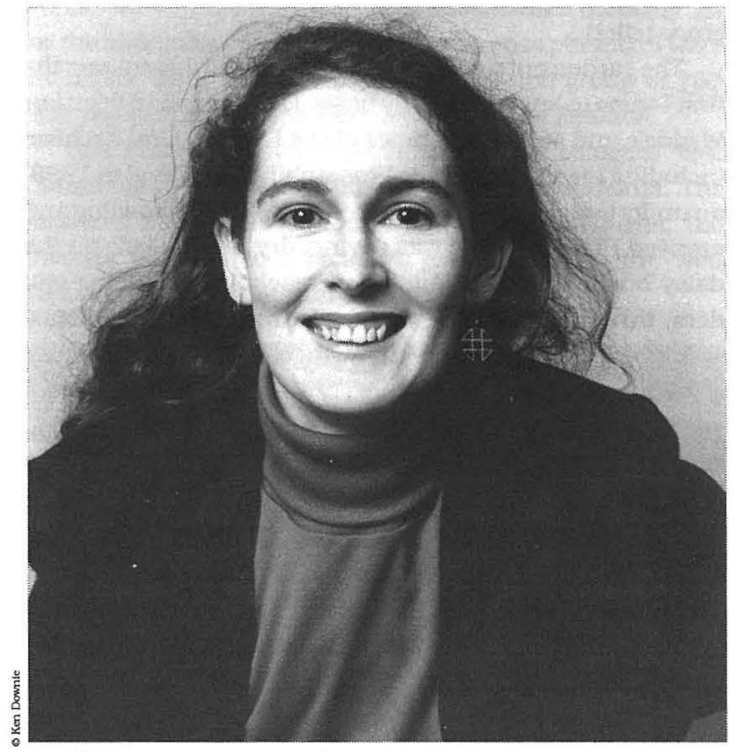

These consecutive pleasures describe my time here. Hours of intense engagement with my work, leavened by company and conversation. I learned a good deal from my fellow fellows, the historians, sociologists, linguists, educationalists, anthropologists. My twentieth century New Zealand history was boosted by 30 percent, and I now know a little about Claude Lévi-Strauss; organ music; 'dark el'; biking in Sweden; midnight mass in Notre Dame in 1964; pick-ups with hogs in back; why plains are said to be not 'flat' but 'level' - and the rest. I have a collection of halfdigested anecdotes about the politics of various universities. I know those names whereby hang tales, my fellow fellows' partners, children, colleagues, friends - and their habits, hopes, some apt stories - most of whom I never met. All 'research' for any novelist or nosey creature.

What has it been like?

In January there was an eclipse. Nelson Wattie and his wife Elfie made a punctured-carton device with which to watch the star crossed. We stood on the deck in gusty sunlight and saw the greens go plush, the shows diluted - 
a grey dusk with noon shadows. Or - Theresa Sawicka and I would have one of our conversations; both so quixotic, we would get over-excited and have trouble fitting our cloudy heads back into the vice of our books. During one conference, or review, or meeting, one of two men outside my door, talking about their university department, uttered the wonderfully quotable, 'Well, of course you'll always have these kind of problems where there's such a concentration of intellect.' Or - Jim Collinge's daughter would come in to visit him - once I heard her say 'I went to sleep in my lecture', pleased with herself, which reminded me of what it felt like to be a young student (the protagonist of my 'me at twenty-three' stories isn't me at twenty-three, but me, the story-teller).

The garden outside the window of my third room was the first I came to know on a daily basis. (The room had been Ian Wedde's and still stored tapes of the Literary Oral Archive, including me reading at the Woman's book festival in 1988 , an undertow of terror in my voice, and in 1989, drawling and amused.) The garden, I was saying, dry, dead heads on the daisy bush; then seeding, full of blackbirds catching spiders, thrushes brushing the shells from skewered snails; wax-eyes, and finches, tiny red-winged birds who seemed to move around in spheres of zero gravity. In winter there were white violets, then the gardeners tore up the garden and redistributed the stones that held it together. Now sparrows come and waggle their bellies in the dry dirt to brush off mites - sometimes a dozen birds at a time, downy cinders swept away at once if a student's foot clanks on the metal grill over the drain on the steps between Stout and Jenness.

I sat at my desk and wrote my two drafts longhand, then a third on disc. Each time I mechanically transcribed my words I got rid of what made me impatient, what was unlovely or inessential. I prefer hand-writing to type because it isn't falsely reassuring. If I write two or three drafts longhand, reading them aloud, the text doesn't set, doesn't look authentic too soon. Handwriting ghosts not only the bodily sounds of speech, but its sensuous pauses. Typed question marks, semi-colons, full stops are not gestures written they are, minute, but meaningful, like finger movements in Thai dancing. I wrote my pages, decisive and deliberate, not provisional (put it on the screen, see how it looks, how it reads). I wrote down, read aloud, re-wrote, read aloud, typed out. Asking, each time my nib lifted from the paper, 'Do I mean this? Is this what I really mean?'

That was what it was like. I hung about like Edward Gorey's doubtful guest, peering up flues and picking the soles from my white canvas shoes. I met the other PEN Stout fellows; Jan Kemp, Judith Holloway, Janette Galpin, Sarah Quigley. I wrote two more essays, one, my 'vulgar manifesto' with the help - though they may not know it - of Theresa Sawicka, Winifred Bauer and Jan Kemp. I finished my novel. All year I was busy and content.

Elizabeth Knox's novel, 'Treasure', is to be published by Victoria University Press in June, 1992.

\title{
1992 STOUT RESEARCH CENTRE CONFERENCE
}

\author{
Friday 14 August - Sunday 16 August \\ 'The bit in between'
}

The title refers to the period between the Armistice and the Spanish Civil War. Speakers will investigate aspects of the history, society and culture of New Zealand between the wars.

The Great Depression, as a prelude to the social changes of the later thirties and forties, has received much attention. What about the period which immediately preceded the Depression?

Few people have made a study of the twenties, yet with a spell of three-party government, the establishment of marketing boards for primary produce, and the growth of women's organisations, it was a time of particular interest for today.

\section{Anyone who wishes to offer a paper at the Conference is asked to contact the Director as soon as possible.}

Stout Research Centre, V.U.W., P.O. Box 600, Wellington. Ph. (04) 472-1000, ext. 8877. 